\title{
Realizm filozoficzny Polskiej Szkoly FilozofiI KLASYCZNEJ JAKO PODSTAWA MODELU WYCHOWANIA OTWARTEGO NA RELIGIE
}

\section{Philosophical realism of the Polish School of Classical Philosophy as the basis for a model of education open to religion}

Summary: The article examines the problem of philosophical realism and its implications for the theory of education concerning the issue of religion. The analysis is based on the works of the Polish School of Classical Philosophy, which continues the tradition of ancient and medieval philosophers, primarily Aristotle and St. Thomas Aquinas. The School goes back to the late 1940 s when, after World War II, the Catholic University of Lublin became a Mecca for researchers that represented realistic philosophical thought. The most important philosophers are Jerzy Kalinowski, Stanisław Kamiński, Mieczysław Albert Krąpiec, Marian Kurdziałek, A. Maryniarczyk, Stefan Swieżawski, Karol Wojtyła, and Zofia J. Zdybicka. The article consists of six parts. Part 1 explains the model of classical philosophy practiced by the School, which is wisdomoriented, and argues that this model contains the determinants of the model of education open to religion. Part 2 deals with a subject of cognition, as pointed out by the School, which criticizes Cartesian, Kantian and phenomenological philosophy (the so-called philosophy of reflection). The approach to the problem of reflection and the priority of objective cognition are the core of realism presented by the School. The issue of unity of being and thinking is further analyzed in Parts 3-4, which deal with the value of pre-scientific cognition and the object of philosophical cognition (the concept of being as being). Parts 2 to 4 show the impact of objective-oriented philosophy on the definition of religion proposed by the School. The specificity of the explanation related to the phenomenon of religion and education is examined in Parts 5 and 6 - while Part 5 addresses the problem of the objectivity of value (including sanctity), the focus of Part 6 is on the metaphysical character of this definition.

Ke y w o r d s : Polish School of Classical Philosophy, realism, Jerzy Kalinowski, Stanisław Kamiński, Mieczysław A. Krąpiec, Marian Kurdziałek, Andrzej Maryniarczyk, Stefan Swieżawski, Karol Wojtyła, Zofia J. Zdybicka 
Początek działalności Polskiej Szkoły Filozofii Klasycznej ${ }^{1}$ przypada na koniec lat czterdziestych ubiegłego wieku i wiąże się z wydziałem filozoficznym Katolickiego Uniwersytetu Lubelskiego (KUL). Po drugiej wojnie światowej KUL stał się jedynym niezależnym od ideologii marksistowskiej ośrodkiem naukowym w Polsce i skupiał badaczy, którzy nie chcieli poddać się koniunkturalnym uwarunkowaniom politycznym ${ }^{2}$. W tym okresie wielu naukowców reprezentujących realistyczną myśl filozoficzną złączyło swoją naukową działalność z uniwersytetem. Dzięki wspólnie prowadzonym badaniom z zakresu metafizyki, antropologii, historii filozofii i metodologii powstało spójne środowisko filozoficzne, które kontynuowało wielką tradycję klasycznej filozofii realistycznej - głównie myśl Arystotelesa i św. Tomasza z Akwinu.

Na dorobek Szkoły składa się praca kilku pokoleń filozofów. Wymieńmy takie postaci jak: Jerzy Kalinowski, Stanisław Kamiński, Mieczysław Albert Krąpiec, Marian Kurdziałek, Stefan Swieżawski, Karol Wojtyła, Zofia J. Zdybicka, a także Andrzej Bronk, Jerzy Gałkowski, Piotr Jaroszyński, Andrzej Maryniarczyk, Piotr Moskal, Henryk Kiereś, Tadeusz Styczeń, Andrzej Szostek. Po zmianach politycznych w latach dziewięćdziesiątych wielu absolwentów Wydziału Filozoficznego KUL (w tym autorka niniejszego tekstu) znalazło zatrudnienie winnych ośrodkach akademickich.

Związek pomiędzy koncepcją wychowania otwartego na religię a koncepcją filozofii został poddany szczegółowej analizie w książce Wychowanie otwarte na religię. Polska Szkoła Filozofii Klasycznej o roli religii w wychowaniu ${ }^{3}$. Problem realizmu też został w niej uwzględniony, chociaż nie stanowił centrum analiz. Ze względu na temat drugiego Seminarium Polskiej Myśli Pedagogicznej, którym było znaczenie realizmu filozoficznego w rozwoju polskiej myśli pedagogicznej, uważamy za cenne uzupełnienie rozważań prezentowanych we wspomnianej książce o spojrzenie na kwestie religii i wychowania wyłącznie z perspektywy realizmu charakterystycznego dla Szkoły; w prezentacji uwzględnimy także podstawowe informacje dotyczące jej powstania i rozwoju. Podyktowane jest to faktem, że problem wychowania z pozycji realistycznej filozofii klasycznej interesuje także badaczy „spoza” Szkoły4, a sam realizm whistorii filozofii niejednokrotnie był przedmiotem dyskusji. Nasze rozważania ujmiemy w sześciu częściach poświęconych kolejno: (1) klasyczności i (2) przedmiotowości filozofii, (3) ocenie poznania spontanicznego, (4) koncepcji przedmiotu filozofii i (5) wartości oraz (6) metafizycznemu modelowi rozważań.

\footnotetext{
${ }^{1}$ W artykule używana jest pełna nazwa „Polska Szkoła Filozofii Klasycznej” oraz skrót - „Szkoła”.

${ }^{2}$ Zob. Mieczysław A. Krąpiec, Andrzej Maryniarczyk, The Lublin Philosophical School (Lublin: PTTA 2010); Andrzej Maryniarczyk, Mieczysław A. Krąpiec, „Szkoła Lubelska Filozofii”, w: Powszechna Encyklopedia Filozofii, red. tegoż i in. (Lublin: PTTA 2005), t. 6, 532-550; Stanisław Janeczek, Filozofia na KUL-u. Nurty - idee - osoby (Lublin: RW KUL 1999).

${ }^{3}$ Zob. Maria M. Boużyk, Wychowanie otwarte na religię. Polska Szkoła Filozofii Klasycznej o roli religï $w$ wychowaniu (Warszawa: Wydawnictwo UKSW 2013).

${ }^{4}$ Zob. np. Jacek Woroniecki, Jacques Maritain, Wojciech Feliks Bednarski, Mieczysław Gogacz i inni.
} 
Dodajmy także, że koncentrując się na podstawach modelu wychowania otwartego na religię, tkwiących w realizmie Szkoły, będziemy tylko „doprowadzać” czytelnika do punktu, w którym zbiegają się kwestie realizmu oraz wychowania i religii. Nie widzimy bowiem potrzeby szerszego treściowego omawiania modelu wychowania otwartego na religię opracowanego we wspomnianej książce.

\section{Filozofia klasyczna}

Klasyczność uprawiania filozofii wiązano z trzema głównymi cechami poznania filozoficznego: metafizycznością oraz metodologicznym i historycznym ugruntowaniem badań5. Charakterystyczny dla Szkoły realizm, tak w wymiarze metafizycznym, jak i epistemologicznym, jest zrozumiały tylko w perspektywie wyżej wymienionych cech klasyczności. One zadecydowały też o dynamizmie prowadzonych badań. Członkowie Szkoły skoncentrowali się na poznawaniu oryginalnych tekstów średniowiecznego myśliciela Tomasza z Akwinu i poszukiwaniach realistycznej formuły filozofii bytu jako teorii adekwatnie wyjaśniającej całą rzeczywistość. Kanwą poszukiwań były aktualne problemy filozoficzne, które ujawniały potrzebę określenia przedmiotu filozofii ze względu na konsekwencje poznawcze stanowisk idealistycznych, w szczególności kantyzmu i fenomenologii ${ }^{6}$. Filozofowano więc w duchu twórczym i kontemplatywnym.

Mimo że filozoficzna myśl św. Tomasza z Akwinu była dla nich ważnym punktem odniesienia, woleli nazywać uprawianą przez siebie filozofię „klasyczną” a nie „tomizmem”, odcinając się w ten sposób od wcześniejszych interpretacji Tomaszowych dzieł. Trzeba pamiętać, że od XV wieku tomizm stanowił dla chrześcijaństwa oparcie ideologiczne. Ciążące na nim odium skostniałej scholastyki próbowano zdjąć, powracając do źródeł metafizyki Tomasza, a więc do jego oryginalnej koncepcji bytu oraz analizując jej ewolucję w pismach następnych pokoleń filozofów. Pomimo to „zaszufladkowanie” tomizmu jako nienowoczesnego modelu filozoficznego dyskursu niesłusznie stygmatyzuje Szkołę i jej olbrzymi dorobek badawczy. Najprawdopodobniej dlatego jej tezy metafizyczne i antropologiczne z trudem znajdują uznanie w naukach humanistycznych i społecznych - także w pedagogice7.

Szkoła nie stanowiła nigdy formalnego i doktrynalnego monolitu, a poznanie filozoficzne oznaczało dla tworzących ją myślicieli możliwość prowadzenia dyskusji wokół spornych kwestii w celu dotarcia do prawdy. Wśród filozofów Wydziału

\footnotetext{
${ }^{5}$ Zob. Andrzej Bronk, Stanisław Majdański, „Klasyczność filozofii klasycznej”. Ruch Filozoficzny 1 (199192): 39-40, 367-391; Andrzej Bronk, Stanisław Majdański, „Filozofia klasyczna”, w: Leksykon filozofii klasycznej, red. Józef Herbut (Lublin: TN KUL 1997), 223-225.

${ }^{6}$ Zob. np. Stanisław Kamiński, Jak filozofować? (Lublin: TN KUL 1989); Mieczysław A. Krąpiec, Poznawać czy myśleć. Problemy epistemologii tomistycznej (Lublin: RW KUL 1994).

${ }^{7}$ Elementy filozofii Szkoły dla potrzeb pedagogiki wykorzystują np. Stefan Kunowski, Adolf Szołtysek, Marian Nowak. Pełne opracowanie wychowania woparciu o filozofię Szkoły przyniosła opublikowana ostatnio książka Barbary Kiereś U podstaw pedagogiki personalistycznej. Filozoficzny kontekst sporu o wychowanie (Lublin: PTTA 2015).
} 
Filozoficznego KUL byli nie tylko zwolennicy tomizmu egzystencjalnego, ale także pewnych postaci fenomenologii, neokantyzmu i filozofii analitycznej. Dlatego w sensie ścisłym o Szkole można mówić w odniesieniu do pewnych specjalizacji oraz osób znaczących w środowisku filozofów KUL, na przykład historyczno-filozoficznej szkoły Stefana Swieżawskiego czy Zakładu Metafizyki, którego badacze odwołują się wyraźnie do stylu filozofowania i rozważań sformułowanych przez Mieczysława A. Krąpca. Twórcom Szkoły zależało przede wszystkim na odnowieniu klasycznej formuły filozofii jako miłości mądrości i na realistycznej perspektywie badawczej.

Zaznaczmy, że Szkoła dyskutowała nie tylko z marksizmem, ale przede wszystkim z postawami poznawczymi, które dominowały w filozofii od czasów nowożytnych, przesuwając punkt wyjścia badań filozoficznych z bytu na analizę danych świadomości. Wskazywała przy tym na związek ujęć poznawczych i rozwiązań ontologicznych, co rzutowało, jak będziemy próbowali pokazać, na podjęty przez Szkołę namysł wzakresie antropologii, w tym religii. Jednym słowem charakterystyczna dla Szkoły „klasyczność” była wyrazem próby powrotu do modelu filozofowania przed-kartezjańskiego, a więc filozofowania w perspektywie bytu (przedmiotu), a nie cogito (podmiotu). Próba ta oznaczała konieczność wypracowania metodologii badań i analizy wielu problemów, które dynamizowały rozwój poznania filozoficznego od wieku XVII ${ }^{8}$. Do znaczących należał problem granic poznania, a w szczególności tak zwany problem „mostu”, czyli tego, jak prawomocnie przejść w poznaniu filozoficznym od danych świadomości do wypowiedzi o bycie. Wypracowane przez Szkołę rozwiązanie odzwierciedla klasyczną, to jest przedmiotową (a w tym sensie - realistyczną) specyfikę filozofii Szkoły. W związku z tym już w następnej części naszych rozważań nawiążemy do zaznaczonego problemu przedmiotowości refleksji filozoficznej i zasygnalizujemy jego wagę dla kwestii wychowania zorientowanego na religię. Chodzi przede wszystkim o odczytanie roli świętości w formacji humanistycznej człowieka z perspektywy problemu zdolności rozumu do poznania obiektywnej prawdy o osobowym dobru.

Formuła realizmu jako zapis klasyczności filozofii odciska się mocno na badaniach Szkoły skoncentrowanych wokół zagadnień nas interesujących, a więc religii jako fenomenu kulturowego, religijności człowieka jako świadomego przeżywania własnej pozycji egzystencjalnej, a także wychowania jako pełnego realizowania potencjalności człowieka ze względu na obiektywne dobro. Wskazane przez nas elementy „klasyczności” Szkoły - koncepcja filozofii jako metafizyki, metodologia badań i historyzm - składają się na to, co można nazwać modelem wychowania otwartego na religię Polskiej Szkoły Filozofii Klasycznej. Uprzedzając bardziej szczegółowe wyjaśnienia, nadmieńmy tylko, że chodzi o model wychowania, w którym, podążając za wielkimi klasykami filozofii antyku i średniowiecza,

\footnotetext{
${ }^{8}$ Jednym z najważniejszych dzieł dotyczących współczesnej teorii i metodologii filozofii klasycznej, a powstałym w wyniku współpracy dwóch znaczących filozofów Szkoły - metafizyka Mieczysława A. Krąpca i metodologa Stanisława Kamińskiego - jest książka Z teorii i metodologii metafizyki (Lublin: TN KUL 1962, wyd. 3 popr. Lublin: RW KUL 1994).
} 
akcentuje się problemy ostatecznego celu ludzkiego życia, wolności ludzkich wyborów ze względu na umiejętność rozpoznania dobra w konkretnych sytuacjach życiowych i możliwość wychowywania ludzkiego sumienia do obiektywnego dobra oraz niezbywalność swego rodzaju duchowego fitness jako nieustannej praktyki ochrony ludzkiej godności.

Na zakończenie tej części naszych rozważań dodajmy, że dojrzałość człowieka - cel zabiegów wychowawczych - w jakiś sposób zawsze harmonizuje z dojrzałością charakterystyczną dla wyznawanej przez niego religii, na przykład chrześcijaństwa. W związku z tym należy zaznaczyć, że pojęcie otwartości na religię odnosi się nie tylko do działań wychowawczych mających na celu wskazywanie wychowankowi transcendentnego wymiaru życia oraz kształtowania jego wrażliwości religijnej czy postaw tolerancji. Ono dotyczy także możliwości krytycznego oglądu humanizmu realizowanego w konkretnych konfesjach religijnych.

Oba wymiary otwartości domagają się filozoficznego uzasadnienia. Pierwszy z nich koncentruje się głównie na uzasadnieniu religijności człowieka, wyjaśnieniu, czym jest wartość świętości i jaką rolę pełni religia w kulturze, natomiast drugi pozwala na ocenę antropologicznych podstaw wychowania wyznaniowego. W książce Wychowanie otwarte na religię... przeprowadzono taką ocenę przy zastosowaniu narzędzi, jakie daje filozofia Szkoły w odniesieniu do antropologii chrześcijańskiej9. Uważamy, że filozoficzne rozpoznanie relacji zachodzących między chrześcijańskim rozumieniem świętości a wartościami humanistycznymi jest ważne dla współczesnej pedagogiki ze względu na pogłębiającą się laicyzację europejskich społeczeństw, jak też wynikające z tego, coraz wyraźniej dostrzegane, niezrozumienie istoty kultury chrześcijańskiej. Ze względu na podjęty w niniejszym artykule temat realizmu podkreślmy, że koncepcja filozofii, jej realistyczna bądź idealistyczna formuła, rzutuje na prezentowane rozwiązania przywołanego problemu.

\section{Filozofia przedmiotu}

Filozofia Szkoły stanęła w opozycji do całego dziedzictwa filozofii kartezjańskiej, tak zwanej filozofii refleksji (inaczej: filozofii podmiotu), która obrała jako przedmiot badań ludzkie myślenie. Perspektywa badawcza właściwa filozofii refleksji miała decydujący wpływ na formułowane w niej ontologie i tezy antropologiczne. Jak uzasadniali filozofowie Szkoły, większość mankamentów obciążających ten model filozofowania (idealizm, dualizm antropologiczny, solipsyzm), wiązało się z brakiem metateorii refleksji, a w szczególności - zaniedbaniem problemu jej źródeł i granic ${ }^{10}$. Dyskutując ze stanowiskami idealistycznymi, przyjęto w Szkole kierunek na pogłębioną analizę poznania spontanicznego, które, jak pokazywano, warunkuje

\footnotetext{
${ }^{9}$ Zob. więcej Boużyk, Wychowanie, 251-304.

${ }^{10}$ Zob. Wojciech Chudy, Rozwój filozofowania a „pulapka refleksji”. Filozofia refleksji i próby jej przezwyciężenia (Lublin: RW KUL 1995), 349-352.
} 
refleksję i jest wzbudzane przez byt. W ten sposób podjęto też wysiłek opracowania podstaw realizmu teoriopoznawczego ${ }^{11}$.

Według Mieczysława A. Krąpca, jednego z twórców i głównych filozofów Szkoły, zasadnicze dla realizmu jest utrzymanie przedmiotowej perspektywy badawczej. Dlatego, analizując ludzkie poznanie, skoncentrował się na ustaleniu, które z aktów poznawczych mają charakter przed-refleksyjny, a więc są wolne od schematu podmiot-przedmiot, obecnego w każdym sądzie typu „poznaję coś” ${ }^{2}$. Krąpiec podkreślał, że nawet najbardziej śladowe powtórzenie tego schematu $\mathrm{w}$ filozoficznej interpretacji fundamentów poznania buduje dystans poznawczy, którego w realizmie chce się uniknąć. Jego zdaniem badanie faktu poznania wskazuje, że progiem jest sąd egzystencjalny typu: „istnieje to oto”. Jakkolwiek sąd ten nie jest sądem prawdziwościowym w ścisłym sensie, to jest w pełni aktem poznawczym i warunkuje prawdę $w$ intelekcie poznającego podmiotu ${ }^{13}$. Krąpiec widział w tym sądzie poznawczą reakcję na styk dwóch istnień: istnienia podmiotu $\mathrm{z}$ istnieniem poznawanego bytu. Podkreślał, że jest on wypełniony faktycznością rzeczy, a jako taki osadza ludzkie poznanie w bycie.

Ta teza o jedności bytu i poznania stała się kluczowa dla realizmu teoriopoznawczego Szkoły. Warto w tym miejscu wspomnieć o zaproponowanej przez Krąpca interpretacji faktu ludzkiego i fenomenu samopoznania, mającego, jak wiadomo, charakter w dużej mierze subiektywny. Krąpiec szukał takiego wymiaru tego poznania, który byłby wolny od treści subiektywnego oglądu oraz który można byłoby uznać za poznanie powszechne, podstawowe i bezpośrednie. Jest nim, jak uzasadnil, wymiar egzystencjalny: poznanie siebie od strony istnienia, wyrażone sądem: „Ja jestem”"14.

Formulując teorię sądów egzystencjalnych, Krąpiec zwracał uwagę, że mimo funkcji detonatora poznania są one w poznaniu potocznym praktycznie niedostrzegalne - człowiek koncentruje się zazwyczaj na treści rzeczy, interesuje go, czym coś jest (także w poznaniu własnej tożsamości) ${ }^{15}$. Dopiero analiza filozoficzna uwyraźnia fakt afirmacji istnienia rzeczy i wyodrębnia ten akt wśród innych aktów poznawczych. Odczytanie jego roli w całym procesie poznania i życiu człowieka pozwala na przełamanie ograniczeń idealizmu. Można nawet przyjąć, że w filozofii Szkoły urasta on do zasady warunkującej poznawanie rzeczywistości i samą refleksję ${ }^{16}$. Nie ma więc ani obawy, że ludzkie poznanie ogranicza się - jak $\mathrm{w}$ fenomenologii - do pola świadomości, ani że jest warunkowane immanentnie - jak

${ }^{11}$ Zob. Kamiński, Krąpiec, Z teorï; Mieczysław A. Krąpiec, Realizm ludzkiego poznania (Lublin: RW KUL 1995).

${ }^{12}$ Zob. Mieczysław A. Krąpiec, Metafizyka.Zarys podstawowych zagadnień (Lublin: TN KUL, 1978), 105106; tegoż, O rozumienie filozofii (Lublin: RW KUL 1991), 129-139.

${ }^{13}$ Zob. tegoż, Metafizyka, 117; tegoż, Realizm, 90-95.

${ }^{14}$ Zob. tegoż, Ja - czlowiek. Zarys antropologii filozoficznej (Lublin: RW KUL 1998), 126-131; tegoż, Realizm, 531-532.

${ }^{15}$ Zob. tegoż, Realizm, 72-77.

${ }^{16}$ Zob. tamże, 563-568. 
utrzymywał Kant. Zaznaczmy jeszcze, że szczególne miejsce w filozofii poznania przypisywane przez Krąpca sądom egzystencjalnym w stosunku do aktywności, jaką jest refleksja, nie było równoważne z pominięciem znaczenia fenomenu refleksji w życiu duchowym człowieka. Można to dostrzec w rozwijanej przez niego, jak i innych członków Szkoły, filozofii człowieka, kultury, ludzkiego działania czy wychowania.

Omówione powyżej zagadnienie „progu poznawczego” stanowi newralgiczny punkt realizmu Szkoły, wyrażonego tezą o jedności myśli i bytu. Jego konsekwencji dla teorii wychowania nie da się opisać krótko: jest to łańcuch zależności. Niemniej jednak wśród znaczących dla pedagogiki kwestii można wymienić klasyczną definicję prawdy, a przede wszystkim - całą teorię rzeczywistości, która podpowiada najbardziej powszechne i podstawowe prawdy oludzkim istnieniu oraz daje podstawy do dyskusji z aksjologicznym relatywizmem i agnostycyzmem. Pozwala wreszcie w duchu realizmu postawić na gruncie metafizyki pytanie o religię zarówno w kontekście ludzkiej wolności, jak i ludzkiego poznania (wiary i wiedzy) czy dziedzin kultury, na przykład moralności. Więcej na temat tych zagadnień powiemy w dalszych częściach naszych rozważań.

\section{Poznanie spontaniczne}

Kluczowy dla realizmu Szkoły problem jedności bytu i poznania przekładał się też na charakterystyczne dla niej zauważanie wartości poznania spontanicznego (inaczej: przednaukowego lub zdroworozsądkowego). Krąpiec po prostu podkreślał, że typowy dla człowieka sposób poznawania prowadzi do wiedzy prawdziwej. O jej prawdziwości decyduje zgodność z obiektywnym stanem rzeczy (kryterium jest oczywistość obiektywnie istniejącego przedmiotu). Na poziomie spontanicznego poznania dokonuje się rozpoznanie praw bytu, które kształtują realistyczny sposób ujmowania rzeczywistości: zasady bytu są zasadami poznania (chodzi o zasady tożsamości, niesprzeczności, racji bytu itp. ${ }^{17}$. Poznanie spontaniczne ma charakter całościowy: odczytuje obiektywnie istniejącą rzecz w jej przyporządkowaniu do treści. W tym sensie jest bazą wyjściową dla filozofii i innych nauk.

Według stanowiska Szkoły poznanie spontaniczne ma i przestrzeń refleksji, i swoją wartość (głównie praktyczną), dlatego nie może być pomijane w koncepcji wychowania, w tym wychowania otwartego na religię. Dziś w edukacji mocny akcent pada na fachowość zdobywaną w kształceniu uniwersyteckim - to słuszne. Niemniej jednak cele edukacyjne nie mogą prowadzić do dewaluowania naturalnych dyspozycji poznawczych człowieka. Jak już pisaliśmy, Szkoła przypomina, że wiedza naukowa ma „wzmocnić”, a nie wykluczyć poznanie zdroworozsądkowe. Tego typu wzmocnieniem, także w kwestiach odnoszących się do religii, jest między innymi filozofia. Jej siłę wyjaśniania należy przede wszystkim oceniać w namyśle metafilozoficznym, biorąc pod uwagę takie czynniki, jak precyzacja przedmiotu, celu

\footnotetext{
${ }^{17}$ Zob. tamże, 108.
} 
i metody zawartych w konkretnych koncepcjach filozofii. Oczywiście można także oceniać „wzmocnienie” w perspektywie jej oddziaływań na kulturę czy życie konkretnego człowieka. Zaznaczmy jednak, że w poznaniu filozoficznym, przynajmniej tak, jak jest ono definiowane w Szkole, nie chodzi o potwierdzanie czyichś przekonań, a tym bardziej przekonań religijnych. Cele poznawcze są czysto teoretyczne i jasno sprecyzowane w koncepcji filozofii Szkoły - mianowicie chodzi o ostatecznościowe w porządku bytowym wyjaśnienie rzeczywistości, w tym człowieka czy jego religijności. Na pewno ciekawym projektem badawczym byłoby porównanie praktycznych konsekwencji stosowania w teorii wychowania antropologii wyłanianej w filozofii idealistycznej z ujęciami proponowanymi przez Szkołę.

Nawiązując do tematyki książki Wychowanie otwarte na religię..., trzeba także zaznaczyć, że refleksja Szkoły nad ludzkim poznaniem, a w szczególności teza o możliwości poznania przez człowieka prawdy obiektywnej, jest podstawowa dla wyjaśnienia osobowego rozwoju także w dziedzinie religii. Szkoła mocno akcentuje naturalną zdolność człowieka do wychowywania i bycia wychowywanym: człowiek jest „wychowywalny” właśnie ze względu na właściwą mu naturalną zdolność do poznania obiektywnej prawdy o dobru. Możliwość poznawczego uzgodnienia się człowieka ze światem, będąca wykładnią realizmu Szkoły, to jeden z najważniejszych filarów wychowania, a także podstawa do stwierdzenia, że teoria cnót, w tym cnota religijności, nadaje zasadniczy kształt realistycznemu modelowi wychowania otwartego na religię ${ }^{18}$.

\section{Przedmiot filozofii}

Jak zaznaczono, zadaniem filozofii nie jest interpretacja danych poznania zdroworozsądkowego, ale szukanie ostatecznych racji rzeczywistości w sposób metodycznie uzasadniony. Filozof nie może przy tym zakładać apriorycznie jakichś praw, bo utraci neutralność perspektywy badawczej i kontakt $\mathrm{z}$ istniejącą rzeczywistością. Krąpiec, dyskutując z idealizmem w sprawie granic poznania, podkreślał, że wszelkie próby odpodmiotowego uzasadniania prawdziwości kończą się subiektywizacją wiedzy albo irracjonalizmem. Łatwo więc zrozumieć, dlaczego poszukiwanie neutralnego punktu wyjścia wbadaniach filozoficznych, czyli określenie tak zwanego przedmiotu filozofii, stało się ważne dla badań prowadzonych przez Szkołę.

Cenną inspiracją w formułowaniu koncepcji przedmiotu filozofii okazała się analiza tekstów Tomaszowych, a w szczególności zaproponowanej przez niego koncepcji bytu jako złożonego $\mathrm{z}$ istoty i istnienia. Stała się ona impulsem do wypracowania przez Szkołę własnego poznawczego ujęcia bytu charakteryzującego

\footnotetext{
${ }^{18}$ Zob. więcej Boużyk, Wychowanie, 212-223.
} 
się neutralnością i realizmem ${ }^{19}$. Mianowicie w pojęciu bytu została zaakcentowana konkretna treść oraz aktualizujący ją, proporcjonalny do niej akt istnienia. Ze względu na wagę elementu bytowego istnienia oraz historyczne źródła opracowanej koncepcji czasem nazywa się filozofię Szkoły tomizmem egzystencjalnym.

Filozofowie Szkoły podkreślali, że neutralność tej koncepcji jest gwarantowana wyodrębnieniem czynników bytowych przysługujących każdemu bytowi, a w szczególności wyodrębnieniu istnienia jako aktu pierwszego w porządku bytowym. Akt istnienia nie tylko realizuje treść bytu, ale jest inny w każdym bytowym przypadku. Dzięki wypracowanej koncepcji w wyjaśnieniu filozoficznym proponowanym przez Szkołę nie dokonuje się redukcji jednych bytów do drugich, a afirmacja istnienia, tak wyraźnie podkreślana przez nią w metodzie badawczej, decyduje o realizmie podstawowego filozoficznego ujęcia rzeczywistości i dalszych etapów metafizycznego poznania. Składają się na nie: poznanie pierwszych zasad bytu i jego własności transcendentalnych, odkrycie wewnętrznej struktury bytu oraz racji bytów przygodnych, a więc bytów, do których istoty nie należy istnienie.

Uniesprzeczniając byt, jak podkreślają filozofowie Szkoły, dochodzi się do uznania sądu o istnieniu bytu Absolutnego - pełni istnienia, prawdy, dobra i piękna ${ }^{20}$. Pojęcie Absolutu to filozoficzny odpowiednik religijnego pojęcia „Bóg”. To, że sąd ten nie jest ani arbitralny, ani wprowadzony jako założenie a priori, jak na przykład u Kartezjusza, pozwoliło wypracować definicję religii uwzgledniającą przedmiotowy aspekt relacji religijnej; definicję znaczącą dla teorii wychowania i różną od tych proponowanych w nurtach filozofii idealistycznej. Dla wyjaśnienia warto przytoczyć słowa Zofii J. Zdybickiej, badaczki Szkoły, zajmującej się głównie filozofią religii. „Fenomenologia aktów i czynności religijnych - pisze Zdybicka, komentując ujęcia idealistyczne - dostarcza istotnej wiedzy o człowieku-podmiocie aktów religijnych, analizuje zawartość idei Boga jako osobowego Absolutu. Ontologia - w ujęciu fenomenologicznym - ustala czyste możliwości (treści) idei boskości jako korelatu aktów religijnych, nie upoważnia natomiast do stwierdzenia obiektywnego istnienia Boga"21. Natomiast definicja, którą formułuje sama Zdybicka na gruncie realizmu filozoficznego Szkoły, pokazuje religię jako realną relację miedzy dwoma bytami: realnie istniejącym człowiekiem i realnie istniejącym Bogiem. Uwzględnienie takiej relacji w teorii wychowania wpływa i na wyznaczenie hierarchii wartości, i na odczytanie roli religii w wychowaniu ${ }^{22}$. Możemy także dodać za Zdybicką, że analizy idei Boga prowadzone przez fenomenologów nie pozwalają na wypowiadanie także sądów o naturze Boga, co ma znaczenie dla definiowania religii jako relacji osobowej,

\footnotetext{
${ }^{19}$ Zob. Krąpiec, Metafizyka, 106-120; Andrzej Maryniarczyk, Metoda separacji a metafizyka (Lublin: RW KUL 1985).

${ }^{20}$ Zob. Stanisław Kamiński, Zofia J. Zdybicka, „O sposobie poznania istnienia Boga”, w: Stanisław Kamiński, Światopogląd. Religia. Teologia (Lublin: TN KUL 1998), 179-204.

${ }^{21}$ Zofia J. Zdybicka, „Wyjaśnienie faktu istnienia religii”, w: tejże, Człowiek i religia (Lublin: RW KUL 1984), 280.

${ }^{22}$ Zob. więcej Boużyk, Wychowanie,109-154.
} 
dialogowo-responsorycznej i znajdującej swoje spełnienie w miłości. W odniesieniu do pedagogii chrześcijańskiej można pokazywać, że proponowana przez Szkołę definicja religii koresponduje z ważnym dla tej pedagogii aspektem wertykalnego wymiaru wychowania: wychowawcą jest nie tylko człowiek, ale i Bóg²3.

Na zakończenie dopowiedzmy jeszcze, że wspomniana definicja ze względu na metodologiczny proces jej formułowania odznacza się wysokim stopniem teoretyczności, a jako taka jest bardziej podstawowa niż definicje wyprowadzane na drodze badań religioznawczych ${ }^{24}$. To czyni ją szczególnie cenną dla refleksji pedagogicznej.

\section{Wartość}

Należy zaznaczyć, że kwestia wartości leżąca w polu zainteresowań pedagogiki jest określana przez filozofów Szkoły jako wtórna w stosunku do analiz bytu w jego elementach konstytutywnych ${ }^{25}$. „Wtórność” nie oznacza upośledzonej pozycji tematyki wartości w refleksji filozoficznej, ale jest podyktowana metodologiczną troską o zachowanie podstaw realizmu. Filozofowie Szkoły, dyskutując z idealizmem filozofii kantowskiej i fenomenologii, wiązali wartość z bytem, a nie z powinnością czy jakościami idealnymi. Wartość jest przede wszystkim interpretowana przez nich jako własność bytu (transcendentalna lub kategorialna), o ile jest on przedmiotem aktów intencjonalnych: poznawczych lub wolitywnych. Wartości kluczowe dla integralnego rozwoju człowieka, na przykład religijne, moralne, artystyczne, intelektualne, witalne z perspektywy realistycznej metafizyki mają charakter kategorialny: coś ma większą wartość im doskonałej urzeczywistnia istotę człowieka. Człowiek obcuje z wartościami, a szczególnie z prawdą, gdy otwiera się na rzeczywistość, a nie na dane refleksji (co oczywiście nie jest równoznaczne z brakiem refleksyjności nad swoimi działaniami). Ogląd kontemplacyjny rzeczywistości w oparciu o podstawowe prawa bytu decyduje o rozwoju poznawczym człowieka. Nauka, której znaczenia dla rozwoju cywilizacji i człowieka trudno nie docenić, nie zastąpi dziedziny moralności. Życie moralne to przede wszystkim przestrzeń wewnętrznych decyzji człowieka, ale także związanych z nimi działań, w których urzeczywistniają się przyjmowane przez niego wartości.

Rdzeniem każdej formacji humanistycznej jest przede wszystkim wychowanie moralne - w terminologii Szkoły powiemy: wychowanie do dobra, w tym dobra, którym jest świętość. W perspektywie współczesnej aksjologii wartość wychowawcza świętości nie jest oczywista. Wynika to między innymi z mocnego subiektywizowania wiary. Tymczasem „myślenie wiarą", jakkolwiek zawsze wiąże się z decyzją człowieka, może i powinno być obiektywizowane. Szkoła bardzo podkreśla ten element formacji

\footnotetext{
${ }^{23}$ Zob. tamże, 252-269.

${ }^{24}$ Zob. Stanisław Kamiński, Zofia J. Zdybicka, „Definicja religii a typy nauk o religii”, w: Stanisław Kamiński, Światopogląd, 123.

${ }^{25}$ Zob. np. Stanisław Kamiński, „Jak uporządkować rozmaite koncepcje wartości?”, w: tegoż, Jak filozofować, 293-306; Krąpiec, Metafizyka, 217-219.
} 
humanistyczneje ${ }^{26}$. Oczywiście to stanowisko wpisuje ją w wielką tradycję filozofii chrześcijańskiej, ale jednocześnie akcentuje intelektualny wymiar ludzkich decyzji w kwestiach wiary i działania zgodnie z wyznawanymi wartościami. W świetle tego można powiedzieć, że zmiana konfesji to także doświadczenie poznawcze człowieka, które domaga się obiektywizacji.

Według przedstawicieli Szkoły religia istotnie wpływa na osobowy, integralny rozwój człowieka. Dostrzega się jej związki z moralnością - wymaga od człowieka świadomych i wolnych decyzji, które mają realny wpływ na jego postępowanie. Te zależności nie pozwalają jednak na redukowanie religii tylko do moralności.

Filozofowie Szkoły postrzegają religię jako dziedzinę, która znajduje swoje uniesprzecznienie w sposobie istnienia człowieka jako człowieka: w jego przygodności, transcendencji, otwarciu na Boga. Jak zauważają Stanisław Kamiński i Zofia J. Zdybicka „[...] religia stanowi osobową, egzystencjalną relację człowieka do osobowego transcendentnego (i równocześnie obecnego w człowieku), realnego Absolutu-Boga. Relacja ta ukształtowana jest ostatecznie przez miłość między «ja» $\mathrm{i}$ «Ty». Jej podstawą jest zaś osobowa struktura ludzkiego bytu, zawierającego określone potencjalności. Człowiek rozwija się przez aktualizowanie swoich potencjalności, specjalnie potencjalności poznawczej i potencjalności miłości, a ostatecznie uniesprzecznia się przez związek z Najwyższą Prawdą i Najwyższym Dobrem" 27.

Porównując powyżej zacytowane słowa z rozpowszechnionym pod wpływem interpretacji Schelera przekonaniem, że przedmiotem religii jest sacrum jako odrębna i najwyższa kategoria aksjologiczna, której odpowiada w psychice człowieka jakaś sfera absolutna będąca źródłem aktów religijnych, można dostrzec, że religia na gruncie filozofii Szkoły jest wyjaśniana w porządku bytowym. W związku z tym jest czymś więcej niż zjawiskiem kulturowym, nie podlega relatywizacji i nie daje się sprowadzić do subiektywnych przeżyć człowieka ${ }^{28}$. Religia to realna, osobowa i responsoryczna relacja człowieka z Bogiem, mająca siłę przemieniania człowieka od wewnątrz. W związku z tym wychowanie z ukierunkowaniem na świętość nie stanowi w ujęciu Szkoły jakiejś indywidualistycznej autokreacji, ale opiera się na wiedzy o rzeczywistości i naturze człowieka. W wychowaniu chodzi o przygotowanie wychowanka do podejmowania odpowiedzialności za dokonywane wybory w świetle obiektywnego dobra i prawdy o człowieku.

Bytowa perspektywa istnienia, którą odnajdujemy w realistycznej filozofii Szkoły, uzasadnia nie tylko otwartość człowieka na Boga (człowiek jako capax Dei), jego naturalną religijność, ale pozwala także pedagogice znaleźć fundament dla dostrzeżenia miary doskonalenia człowieka i potwierdza wychowawcze intuicje na

${ }^{26}$ Zob. Mieczysław A. Krąpiec, Ludzka wolność ijej granice (Lublin: PTTA 2008), 87-88; tegoż, „Rozumnie wierzyć - rozumnie poznawać. Czytając Encyklikę «Fides et ratio»”, w: tegoż, Filozofia w teologï (Lublin: Wydawnictwo FSVM 1999), 131-146.

${ }^{27}$ Kamiński, Zdybicka, „Definicja”, 117.

${ }^{28}$ Zdybicka, „Wyjaśnienie”, 280. 
temat potrzeby indywidualnego podejścia do każdego wychowanka. Zaznaczmy, że nazywanie człowieka bytem z natury religijnym dokonuje się ze względu na rozpoznanie ontycznego statusu ludzkiego bytu. W związku z tym religijny potencjał człowieka jest rozumiany jako fragment odczytanej prawdy o ludzkiej godności. Jego realizacja wymaga pracy wychowawczej i autowychowawczej ${ }^{29}$.

\section{Metafizyka}

Szkoła w swoich badaniach od początku uwzględniała kontekst przemian filozofii na przestrzeni wieków. Szukała wyjaśnienia poznawczej i metodologicznej specyfiki filozofii klasycznej, tak w stosunku do innych sposobów prowadzenia refleksji filozoficznej, jak i różnych dyscyplin naukowych. Dzięki temu u badaczy Szkoły tworzyła się pogłębiona świadomość realizmu poznania filozoficznego, a ich polemiki z marksizmem i nurtami idealistycznej filozofii opierały się na mocnych podstawach teoretycznych także w kwestiach antropologicznych. Przede wszystkim w filozofii człowieka obowiązywała (i nadal obowiązuje) perspektywa bytowa, a nie świadomościowa: odkrywanie istoty ludzkiego bytu rozpoczyna się od ukazania szczególnej pozycji człowieka w świecie przyrody i jest autonomiczne w stosunku do badań prowadzonych w innych dziedzinach nauk. Gwarantuje to z jednej strony obiektywny kierunek analiz oraz podkreśla trud samostanowienia człowieka w obiektywnie istniejącym świecie, a z drugiej - podkreśla fundamentalność refleksji metafizycznej w stosunku do aspektów badawczych na przykład nauk humanistycznych lub społecznych. Zdaniem Szkoły realistycznie budowana integralna wiedza o człowieku, dodajmy - bezwzględnie potrzebna pedagogom - wymaga dobrego rozpoznania przedmiotów i aspektów badawczych poszczególnych nauk.

Rozwój Szkoły przeszedł przez kilka etapów, co sygnalizuje też ewoluowanie jej nazwy ${ }^{3}$. Do połowy lat sześćdziesiątych ubiegłego stulecia trwało formułowanie naukowego programu. Na ten okres przypada również rozwój refleksji metodologicznej, a więc dokonuje się wypracowanie narzędzi niezbędnych do uprawiania realistycznej filozofii. Kolejne lata przynoszą eksplorację rzeczywistości według założonych celów badawczych, w tym pogłębioną refleksję antropologiczną. W obliczu marksistowskiej ideologizacji życia publicznego Szkoła aktywnie włącza się $\mathrm{w}$ dyskusje na temat ważnych kwestii kulturowych, upominając się przede wszystkim o prawdę o człowieku. Należy podkreślić, że cele antropologiczne badań rysowały się dla środowiska Szkoły jako zasadnicze, niemniej jednak zdawano sobie sprawę, że nie można ich zrealizować bez wypracowania gruntownych podstaw metafizycznych.

\footnotetext{
${ }^{29}$ Zob. więcej Boużyk, Wychowanie , 209-249.

${ }^{30}$ Zob. Krąpiec, Maryniarczyk, The Lublin, 11; Mieczysław A. Krąpiec, Andrzej Maryniarczyk, „Szkoła Lubelska Filozofii”, w: Powszechna Encyklopedia Filozofii, red. Andrzej Maryniarczyk i in. (Lublin: PTTA 2005), t. 6, 532-550. Autorzy wymieniają następujące nazwy: Lubelska Szkoła Filozoficzna, Lubelska Szkoła Filozofii Klasycznej, Lubelska Szkoła Filozofii Chrześcijańskiej, Szkoła Lubelska, Polska Szkoła Filozofii Klasycznej.
} 
Znalazło to wyraz w sformułowanej definicji poznania filozoficznego jako poznania metafizycznego badającego byt $\mathrm{w}$ aspekcie istnienia.

Wojciech Chudy, jeden z filozofów Szkoły, komentuje wagę tego kierunku badań dla refleksji antropologicznej i pedagogicznej wnastępujący sposób: „Zgłębianie bytu jest rzeczą trudną. Otwieranie nowych problemów, odkrywanie tego, co jest elementem wyjaśniającym byt, budowa struktury bytu, pojęcie transcendentalności - to wymiary niezwykle trudne do uchwycenia i zrozumienia. Najwyraźniej można to unaocznić, zestawiając modus filozofii realistycznej z dzisiejszą salonową modą postmodernistycznego filozofowania, gdzie kilka metaforycznych pojęć wartościujących - typu: pielgrzym, turysta, błazen czy kapłan - pretenduje do całej ludzkiej rzeczywistości”31.

Kwestie realizmu teoriopoznawczego i metafizycznej formuły filozofii charakterystyczne dla Szkoły rzutują, jak wielokrotnie podkreślaliśmy, na rozwiązania kwestii antropologicznych istotnych dla teorii wychowania, w tym wychowania otwartego na religię. Uzupełniając wskazywane już zależności, można dodać jeszcze specyficzne dla ducha Szkoły rozumienie innych podstawowych dla wychowania pojęć: godności osoby, rozwoju człowieka czy sprawności moralnych ${ }^{32}$. Jednym słowem w wyjaśnianiu roli wychowania otwartego na religię najważniejsze jest rozumienie samej rzeczywistości. W procedurze badań metafizycznych pierwszeństwo nad całą refleksją antropologiczną (w tym poświęconą religii) mają badania nad bytem (tak zwana metafizyka ogólna). W filozofii kultury, filozofii religii analizuje się ludzkie działania i dlatego dyscypliny te zaliczane są do szczegółowych (to jest do typów metafizyki szczegółowej)33.

Specyfikę procedury badawczej Szkoły i realizmu jej filozofii można prześledzić także na przykładzie wyłaniania wspominanej już definicji religii w ujęciu Zdybickiej. Punktem wyjścia podjętej przez nią analizy jest dany w przeżyciu religijnym i wyrażony zrachowaniami religijnymi fakt odniesienia człowieka do rzeczywistości dla niego transcendentnej. Dalej badaczka podejmuje próbę ontologicznej artykulacji tego faktu. Korzystając z ustaleń metafizycznych i antropologicznych, wyróżnia podmiot, przedmiot i podstawę relacji religijnej.

Trzeba zaznaczyć, że najważniejsze dla prowadzonych przez badaczkę rozważań są uniesprzecznienia bytu jako takiego (a więc wspomniana teza o istnieniu i naturze Absolutu) oraz bytowości człowieka. Chodzi o ukazanie, że człowiek jest bytem partycypującym w istnieniu Absolutu-Boga jako osoba ontycznie otwarta na drugie „ty”, a także na „Ty” nieskończone. Zwieńczeniem rozważań, przedstawionych przez nas z konieczności skrótowo, jest zaproponowana przez Zdybicką następująca definicja religii: „W ujęciu filozoficznym religia jest realną i dynamiczną relacją

\footnotetext{
${ }^{31}$ Wojciech Chudy, „Rola intelektu jako recta ratio w poznaniu realistycznym”, w: Osoba i realizm w filozofii, „Zadania Współczesnej Metafizyki” nr 3/4 (Lublin: PTTA 2002), 197.

${ }^{32}$ Zob. więcej Boużyk, Wychowanie, 155-250.

${ }^{33}$ Zob. Stanisław Kamiński, „Osobliwość metodologiczna teorii bytu”, w: tegoż, Jak filozofować, 71-88 oraz tamże: „Dziedziny teorii bytu”, 177-194.
} 
osobową człowieka do osobowego Absolutu, od którego człowiek jest zależny [nie chodzi, jak w ujęciach subiektywistycznych, o poczucie zależności - przyp. MMB] w istnieniu oraz działaniu i który jest jego ostatecznym celem, nadającym sens jego życiu (przyczyna sprawcza i celowa)"34. Ponieważ sformułowana definicja jest uniwersalnym i transcendentalnym ujęciem faktu religijnego jako istniejącego może stanowić mocny fundament teoretyczny dla modelu wychowania otwartego na religię.

Podsumowując, metafizyczny i teoriopoznawczy realizm Szkoły decyduje o realistycznym charakterze rozwiązań w obszarze badań z filozofii człowieka czy filozofii religii. Te zależności można dostrzec na przykład winterpretacjach religijności człowieka jako naturalnego sposobu jego bytowania czy ontycznych podstaw faktu religii - zarówno przedmiotowych (dotyczących istnienia i natury Boga), jak i podmiotowych (dotyczących istnienia i natury człowieka). W duchu realizmu należy także odczytywać postulat otwarcia wychowania na religię. $\mathrm{W}$ artykule wskazaliśmy na związki tez tworzących fundament takiego modelu z realizmem filozofii Szkoły. Próbowaliśmy spojrzeć na niego w świetle następujących zagadnień: klasycznego modelu filozofii jako aktywności kontemplatywnej w poznawaniu prawdy i związanych z tym zagadnień przedmiotowości refleksji filozoficznej oraz pozytywnej oceny poznania spontanicznego, a przede wszystkim problemu koncepcji przedmiotu filozofii i jej metafizyczności. Ponadto uwzględniliśmy problem wartości ważny dla teorii wychowania.

Najważniejszą dla działań pedagogicznych konkluzją z przeprowadzonych analiz wydaje się stwierdzenie, że religia jest realną relacją osobową doskonalącą w sposób realny człowieka ze względu na coraz pełniejsze zjednoczenie się z dobrem-Bogiem. W świetle realizmu Szkoły nie mówi się o świętości jako idei doskonalącej człowieka, ale mocno podkreśla się, że tylko realne dobro ma moc jego przemiany wewnętrznej, oczywiście o ile zostanie przez niego poznane i pokochane.

Streszczenie: W artykule zostaje podjęty problem filozoficznego realizmu i jego wpływu na teorię wychowania w odniesieniu do kwestii religii. Analizy są prowadzone w oparciu o prace Polskiej Szkoły Filozofii Klasycznej, która kontynuuje tradycję filozofii starożytnej i średniowiecznej, a w szczególności myśli Arystotelesa i Tomasza z Akwinu. Początek działalności Szkoły datuje się na koniec lat czterdziestych ubiegłego wieku, gdy po II wojnie światowej Katolicki Uniwersytet Lubelski stał się mekką dla badaczy reprezentujących realistyczną filozofię. Do najbardziej znaczących filozofów Szkoły można zaliczyć: Jerzego Kalinowskiego, Stanisława Kamińskiego, Mieczysława A. Krąpca, Mariana Kurdziałka, Andrzeja Maryniarczyka, Stefana Swieżawskiego, Karola Wojtyłę, Zofię J. Zdybicką. Artykuł składa się z sześciu części. Część 1 wyjaśnia ukierunkowany na mądrość klasyczny model uprawianej w Szkole filozofii i stwierdza, że ma on wpływ na model wychowania otwartego na religię. Część 2 dotyczy problemu przedmiotu poznania, tak jak jest on przedstawiany przez Szkołę krytykującą ujęcia kartezjańskie, kantowskie czy fenomenologiczne (tzw. filozofię refleksji). Kluczowe dla realizmu Szkoły są stosunek do problemu refleksji i pierwszeństwo poznania przedmiotowego. Kwestia jedności bytu i poznania

\footnotetext{
${ }^{34}$ Zdybicka, Człowiek, 271.
} 
jest poddana głębszej analizie w częściach 3-4, poświęconych wartości poznania przednaukowego i przedmiotowi poznania filozoficznego (koncepcji bytu jako bytu). Części artykułu od 2 do 4 pokazują, jak filozofia zorientowana przedmiotowo wpływa na definicję religii zaproponowaną przez Szkołę. Specyfika filozoficznego wyjaśnienia w odniesieniu do religii i wychowania jest analizowana w częściach 5 i 6, z których pierwsza podejmuje problem obiektywności wartości (w tym świętości), a druga koncentruje się na metafizycznym charakterze definicji religii.

Słowa kluczowe: Polska Szkoła Filozofii Klasycznej, realizm, Jerzy Kalinowski, Stanisław Kamiński, Mieczysław A. Krąpiec, Marian Kurdziałek, Andrzej Maryniarczyk, Stefan Swieżawski, Karol Wojtyła, Zofia J. Zdybicka

\section{Bibliografia}

Boużyk, Maria M. Wychowanie otwarte na religię. Polska Szkoła Filozofii Klasycznej o roli religii w wychowaniu. Warszawa: Wydawnictwo UKSW, 2013.

Chudy, Wojciech. „Rola intelektu jako recta ratio w poznaniu realistycznym”, w: Osoba i realizm w filozofii, 183-204. „Zadania Współczesnej Metafizyki”, nr 3/4. Lublin: PTTA, 2002.

Chudy, Wojciech. Rozwój filozofowania a „putapka refleksji”. Fỉlozofia refleksji i próby jej przezwyciężenia. Lublin: RW KUL, 1995.

Janeczek, Stanisław. Filozofia na KUL-u. Nurty - idee - osoby. Lublin: RW KUL, 1999.

Kamiński, Stanisław. Jak filozofować?. Lublin: TN KUL, 1989.

Kamiński, Stanisław. Światopogląd. Religia. Teologia. Lublin: TN KUL, 1998.

Kamiński, Stanisław, Mieczysław A. Krąpiec. Z teorii i metodologii metafizyki. Lublin: RW KUL, 1994.

Kiereś, Barbara. U podstaw pedagogiki personalistycznej. Filozoficzny kontekst sporu o wychowanie. Lublin: PTTA, 2015.

Krąpiec, Mieczysław A. Filozofia w teologï. Czytając Encyklikę „Fides et ratio”. Lublin: Wydawnictwo FSVM, 1999.

Krąpiec, Mieczysław A. Ja - człowiek. Zarys antropologï filozoficznej. Lublin: RW KUL, 1998.

Krąpiec, Mieczysław A. Ludzka wolność i jej granice. Lublin: PTTA, 2008.

Krąpiec, Mieczysław A. Metafizyka. Zarys podstawowych zagadnien, Lublin: TN KUL, 1978.

Krąpiec, Mieczysław A. O rozumienie filozofii. Lublin: RW KUL, 1991.

Krąpiec, Mieczysław A. Poznawać czy myśleć. Problemy epistemologï tomistycznej. Lublin: RW KUL, 1994.

Krąpiec, Mieczysław A. Realizm ludzkiego poznania. Lublin: RW KUL, 1995.

Krąpiec, Mieczysław A., Andrzej Maryniarczyk. The Lublin Philosophical School. Lublin: PTTA, 2010.

Krąpiec, Mieczysław A., Andrzej Maryniarczyk. „Szkoła Lubelska Filozofii”. W Powszechna Encyklopedia Filozofii, red. Andrzej Maryniarczyk i in., 532-550. Lublin: PTTA, 2005, t. 6.

Maryniarczyk, Andrzej. Metoda separacji a metafizyka. Lublin: RW KUL, 1985.

Zdybicka, Zofia J. Cztowiek i religia. Lublin: TN KUL, 1993. 